\title{
AN INTERACTION BETWEEN MONETARY POLICY, COMMODITY PRICES AND INFLATION IN NIGERIA, 1980-2015
}

\author{
Ephraim Ugwu*,Emma-Ebere Obiajulu \\ Department of Economics, Faculty of Social Sciences, Federal University, Oye-Ekiti, Ekiti \\ State, Nigeria \\ ephraim.ugwu@fuoye.edu.ng \\ Obiajulu.emma-ebere@fuoye.edu.ng
}

\begin{abstract}
This study evaluates the interaction between monetary policy, commodity prices and inflation in Nigeria using an unrestricted Vector Auto Regression (VAR) model and Cointegration test approaches from 1980 to 2015. The study utilizes data on monetary policy rate (MPR), commodity product export (CPE), rate of inflation (INF), industrial production (INDP) and oil price (OILP) for analysis. The descriptive statistics result for the variables under consideration indicates that all the variables have positive mean values with 36 observations. The Unit root test result indicates that all the variables are stationary and are integrated of order one at $5 \%$ level of significance. The cointegration test result indicates at most two cointegrating equations. The impulse response function results indicates that the response of the INF to one standard innovation is positive to its own shock in the short run, it fluctuates and became stable with positive trend along the horizon in the long run. The response of the INF to one standard innovation in the CPE indicates a lower response of negative shock in the initial period with fluctuation, then stabilizes in the long run. The response of the INF to one standard innovation in MPR shows a fluctuation in the short run, but steadily continues its positive trend along the horizon in the long run period. The response of INF to one standard innovation in OILP indicates a negative response in both short and long periods. The variance decomposition result shows that the shock of the INF to itself indicates that it accounts for the most of the variability over all periods, it ranges from $92 \%$ in the short run to 55\% in the long run. The shock of INF to CPE shows a decreasing pattern from the first quarter, ranging from $0.1 \%$ in the short run to $6.5 \%$ in the tenth period. The shock of the INF to MPR indicates a decreasing pattern in the short run from $2.4 \%$, it increases to $24.35 \%$ in the medium run and continues increasing to $32 \%$ in the long run. The study therefore recommends that the Federal Government's attention should be focused on non-oil agricultural commodities for future and stable economic growth in Nigeria.
\end{abstract}

Keywords: Monetary policy, Commodity prices, Inflation, VAR, Cointegration, Nigeria

JEL classification: C40, E31, E44, E52, E58, N17

\section{Introduction}

The downward trend in the global commodity prices and their implications for inflation and monetary policy across countries have created a great puzzle among researchers. Evans and Fisher (2011) observed that since the mid -1980s, sharp increase and reduction in the prices of commodities had minor effect on inflation, but it had no effect on core inflation which is the measure that excludes food and energy prices. Scrimgour (2014) stated that since commodity prices help to determine a wide range of producer and of course consumer prices, commodity prices response to monetary policy and the effect on inflation is an important aspect of monetary mechanism. Melzer (2011) argued that rising commodity

\footnotetext{
* Corresponding author: Ephraim Ugwu
} 
prices are inflationary and therefore require a tightening of monetary policy. Also, Meyer (2011) noted that rising commodity prices have sometimes resulted to higher inflation. According to the author, response of monetary policy may therefore not be required. Bruno and Sachs (1985) on the other hand heaped the blame on the 1970s inflationary rise on commodity prices while Barsky and Kilian(2001) argued that it was in response to an anticipated inflation that was brought on by monetary policy that led to a rise in commodity prices. The inflationary consequences of rising commodity prices result in an increase in inflation, but at the same time, have negative consequences on economic activity. Its monetary implications are not clear cut than those of demand shocks (De Gregorio, 2012). In the year 2008, before the advent of the financial crises, price of commodities fell after surging rapidly to an unprecedented level. But from early 2009, the commodity prices was stable and then continued in upwards shift though characterized by relatively high volatility (Anzuini, Lombardi and Pagano, 2012). As commodity prices in general and particularly the price of oil, are the main parts of Consumer Price Index (CPI), their evolution and the forces behind them are the most important factors for conducting monetary policy (Svenson, 2005). In a quest to investigate channels through which monetary policy affect commodity prices, scholars have noted four different channels of monetary policy effect on commodity prices. Among the channels noted include, extraction channel, Inventory channel, financialisation and exchange rate channels (Frankel, 2014). In the extraction channel, prices of non-renewable resources are reduced by high interest rates through an inducing incentive to extract today instead of tomorrow (Hotelling, 1931). This results to the rate by which oil is drilled and how forest is logged. The inventory channel according to Frankel (2014) results in a decreasing desire to conduct an inventory of commodities due to high rate of interest. The Financialisation channel lead to a shift into purchase of treasury bills by portfolio managers thereby abandoning commodity contract which is considered asset class (Hamilton and Wu, 2014). In the exchange rate channel, it is assumed that internationally traded commodities are reduced in domestic terms even though prices have not fallen in foreign currency terms.Therefore high interest rate strengthens the local currency (Frankel, 2006).

\subsection{Statement of the problem}

In Nigeria, despite the fall in price of crude oil, the Federal Government still receives at least US \$1billion monthly as a share derived from the country's Natural Gas exploration. Despite large amount of money generated and other resources from the country's natural gas, Nigeria has not invested requisite equity to boost earnings from gas exploration (Utomi, 2014). The future of the nation's economy the author noted apart from agriculture, could be anchored on gas utilisation if the Federal Government would be more serious with the gas master plan. Even as Nigeria prides itself as gas province with oil, with about one hundred and eighty seven trillion cubic feet of proven gas reserve, there has been a continuous delay since 1999 in harnessing the huge gas reserve. Also, the implication of the country's reluctance to diversify its commodity exports has resulted to loss of revenue due to oil price fall. As a result, the naira exchange rate has continued to depreciate against the US dollar (Utomi, 2014). Commodity price shock generates mostly a wealth effect, exchange rate as well as aggregate demand shocks. The issue becomes how to manage monetary policy to smooth the commodity price and inflationary shocks (De Gregorio, 2011). As crude oil prices continue to plummet, the Nigerian economy which is solely dependent on the export of crude oil has taken a downward trend with serious effect on country's short-term economic and fiscal growth. The decrease in commodity prices and its inflationary effect hence becomes a monetary policy issue. How then can the Central Bank manage monetary policy in order to smooth the commodity price and inflationary shocks in the economy? What is the monetary policy reaction in the face of commodity prices and inflationary effect in Nigeria? 


\subsection{Objectives of the study}

The objective of this study is to evaluate the interaction between monetary policy, commodity prices and inflation in Nigeria. The specific objectives are:

a. To determine the effect of other macroeconomic variables on inflation in Nigeria

b. To proffer measures that would spur policy reaction in the face of dwindling revenue and high cost of living due to fall in commodity prices in Nigeria

\subsection{Hypothesis of the study}

Based on the objectives listed, hypotheses guiding this study is stated as follows:

i. There is no interaction between monetary policy, commodity prices and inflation in Nigeria

ii. There are no effect of other macroeconomic variables on inflation in Nigeria

\subsection{Scope of the study}

This study covers the period from 1980 to 2015, focusing mainly on time series data from the Central Bank of Nigeria's (CBN) statistical bulletin.

\section{Literature Review}

Studies have been conducted on the interaction effect between monetary policy, commodity prices and inflation. Among scholars include, DeGreorio (2012) who noted that the inflationary consequences of a rise in the prices of commodities denote a significant experiment for monetary policy. According to the author, rising commodity prices leads to a rise on inflation which affect economic activities negatively. An inflationary rise that occurs as result of a positive demand shock in the economy requires monetary policy tightening for effective stabilisation. However, the implications of commodity price shock are clear cut. A commodity price shock generates mostly wealth effect, which affects aggregate demand and exchange rate if the economy is a commodity net importer with relevant demand for the commodity locally (De Gregorio, 2012). As crude oil prices plummeted to $43 \%$ during the course of 2014, Frankel (2014) noted that this is good news for oil importing countries, and for countries like Nigeria, Venezuela, Russia, and other oil exporting countries, it is a bad news. The continuous drop in the prices of oil could be attributed to the recent United States (US's) shale energy boom, while others cite the Organization of Petroleum Exporting Countries (OPEC's) failure to agree on supply restrictions. The price of iron ore also is down, so are gold, silver and platinum prices. And the same is true of sugar, cotton and soybean prices (Frankel, 2014). According to the author, since the beginning of the year 2014, most dollar commodity prices have fallen. Even though there are other factors affecting prices of commodities, the slump in oil price indicates that macroeconomic elements are really at work.

\subsection{Theory of monetary policy effect on inflation}

In the study of monetary policy effect on inflation, scholars have debated for and against reactions of commodity prices with prices of consumer goods. Among the scholars include, Cody and Mills (1991) that were of the view that the most obvious reason adduced is the fact that commodities are traded in auction markets. Adams and Ichino (1995) noted that under rational expectations, the price today will contain all available information and therefore, future prices are expected. In this case, Verheyen (2010) noted that when there is availability of new information, it leads to commodity price changes and final goods prices react quite sluggishly, probably as a result of menu cost or contract restriction. Cheung (2009) assert that a rise in price of commodity might be an indication of a general rise in the world's demand for a finished product due to inflationary pressure. Another line of argument for a slower response of final goods prices according to Verheyen (2010) can be established by 
focusing on price reduction approach. Garner (1989) argue that while commodities are inputs in process of production, they affects costs of production and also consumer goods inflation. Verheyen (2010) noted that this argument is correct only with the assumption that most of the increase in input costs is spread to prices of consumer goods. However, Moosa (1998) raises the objection, insisting that raw material costs are little portion of the entire costs of production. Blomberg and Harris (1995) noted connection between commodity prices and inflation via the use of commodities, especially gold, as an inflation hedge. According to Frankel (1986), individuals may buy commodities when anticipating a price rise in order to avoid depreciation of money.

\subsection{Empirical literature}

Anyanwu and Kalu (2014) ascertain the impact of Central Bank of Nigeria (CBN) money supply on the growth of Nigerian economy from 1994-2012. Applying SPSS for estimation their findings indicate that change in money supply impacts on CBLA and the output positively during the period under review.

Scrimgeour (2014) estimates commodity prices response to monetary policy surprises in the United States using a Standard VAR model approach. The study reveals that a 10 basis-point surprise increase in interest rates leads to a fall in the price of commodity by $0.6 \%$.

Kuhanathan, Sanvi and Lyes (2013) apply Markov-switching models to show that there is an implicit impact of commodity markets on short-term interest rates for US, the Euro area, Brazil, India, Russia and South Africa economies over the period from January 1999 to August 2012. Applying the VAR models, the study reveal that short-term interest rates respond to commodity volatility shocks on all the countries.

Anzuini, Lombardi and Pagano (2012) investigate the interaction between commodity prices and monetary policy for the US economy using a standard VAR model approach. The results reveal that monetary expansion affects broad commodity price index and all of its components. They note that while these effects are significant, they do not, however, appear to be overwhelmingly large.

Okwo, Eze and Nwoha (2012) examine the effect of monetary policy outcomes on macroeconomic stability in Nigeria 1985 to 2010. The regression result show that none of the variables used in the study are statistically significant. The result also indicate an insignificant effect of monetary policy, GDP, private sector credit, net credit to the government and inflation in Nigeria.

\section{Methodology of the research}

In order to evaluate the interaction between monetary policy, commodity prices and inflation in Nigeria, we adopts a Vector Auto Regression (VAR) approach. We apply the standard Choleski decomposition method to our estimated unrestricted VAR models. The VAR process based on normally distributed errors (Gaussian) has frequently been a popular choice for describing macroeconomics time-series data. The main aim behind the application of the Choleski decomposition to our VAR regressions gears towards estimating vector autoregressions with residuals uncorrelated. The Choleski decomposition requires a variable ordering since it gives different results based on different ordering. This ordering of variables is in line with Walsh and Wilcox (1995), Friedman and Kuttner (1993). The triangular VAR form is the sigma and restrictions on A0 respectively. The triangular system is based on a specific ordering of the $p$ variables and thus on an underlying assumption of a causal chain. This model can be extended to the case where there are k lags (2 lags in our case) of each variable in each equation. The model is summarized in the reduced-form VAR model as follows: 


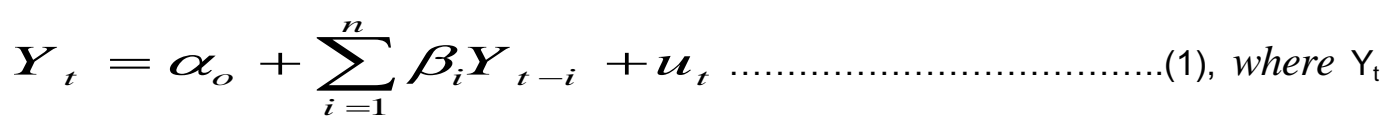

is a $5^{*} 1$ vector of variables (INF, CPE, MPR, INDP, OILP), where:

INF = Inflation

$\mathrm{CPE}=$ Commodity Product Export

MPR $=$ Monetary policy rate

INDP= Industrial production

OILP $=$ Crude oil price

All variables are in normal form. $\beta_{i}$ are coefficient matrices of size $5 \times 5$ and $u_{t}$ is the prediction error ( one step ahead) with variance-covariance matrix $\Sigma, \alpha_{0}$ is the intercept. The structural equation for the model is stated as follows:

$$
\begin{aligned}
& I N F_{\mathrm{t}}=\pi_{0}+\pi_{1} C P E_{\mathrm{t}-1}+\pi_{2} M P R_{\mathrm{t}-1}+\pi_{3} I N D P_{\mathrm{t}-1}+\pi_{4} O I L P_{t-1} \\
& C P E_{\mathrm{t}}=\varphi_{0}+\varphi_{1} \mathrm{INF}_{\mathrm{t}-1}+\varphi_{2} M P R_{\mathrm{t}-1}+\varphi_{3} I N D P_{\mathrm{t}-1}+\varphi_{4} O I L P_{t-1} \cdots \\
& M P R_{\mathrm{t}}=\sigma_{0}+\sigma_{1} \mathrm{INF}_{\mathrm{t}-1}+\sigma_{2} C P E_{\mathrm{t}-1}+\sigma_{3} I N D P_{\mathrm{t}-1}+\sigma_{4} O I L P_{t-1} \cdots \\
& I N D P_{\mathrm{t}}=\gamma_{0}+\gamma_{1} \mathrm{INF}_{\mathrm{t}-1}+\gamma_{2} C P E_{\mathrm{t}-1}+\gamma_{3} M P R_{\mathrm{t}-1}+\gamma_{4} O I L P_{t-1} \cdots \ldots \\
& O I L P_{t}=\beta_{0}+\beta_{1} I N F_{t-1}+\beta_{2} C P E_{t-1}+\beta_{3} M P R_{t-1}+\beta_{4} I N D P_{t-1}
\end{aligned}
$$

\subsection{Variance decompositions and Impulse Response functions}

For this research work, it showed the proportion of variance of the forecast error INF that can be attributed to variation to each of the exogenous variables. A Monte Carlo simulation (with one hundred draws) from the unrestricted VAR is used to generate the standard errors for the impulse response and variance decomposition coefficients. The confidence bands for the response function are $90 \%$ intervals generated by normal approximation. There is no agreement on an clear standard for significance used in a VAR framework; Sims (1987) however suggests that for impulse responses, significance can be crudely gauged by how much functions drifted from zero, whilst Runkle (1987) suggests a probability range above 10 percent for variance decompositions.

\subsection{Sources of data}

This study utilizes data which include, Commodity Product Export (CPE), this consist of commodities other than oil, oil price, industrial production and monetary policy rate, in this case, it is used as monetary policy instrument and inflation from the Central Bank of Nigeria's (CBN) statistical bulletin.

\subsection{Estimation Procedure Unit root test}

To test for stationarity or the absence of unit roots, this test is done using the Augmented Dickey Fuller test (ADF) with the hypothesis which states as follows: If the absolute value of the Augmented Dickey Fuller (ADF) test is greater than the critical value either at the $1 \%$, $5 \%$,or $10 \%$ level of significance, then the variables are stationary either at order zero, one ,or two. The Augmented Dicky Fuller test equation is specified below as follows:

$$
\Delta \widehat{u}_{t}=\beta \bar{u}_{t-1}+\sum_{i=1}^{k} \Delta \bar{u}_{t-1}+\varepsilon_{t}
$$




\section{Cointegration test}

In time series analysis, we often encounter situations where we wish to model one non-stationary time series $\left(Y_{t}\right)$ as a linear combination of other non-stationary time series $\left(X_{1, t}+X_{2, t} \ldots \ldots \ldots \ldots . . . X_{k}, t\right)$. In other words:

$Y_{t}=\beta_{1} X_{1, t}+\beta_{2} X_{2, t} \ldots \ldots \ldots \ldots . . . \beta_{k} X_{k}{ }_{t}+\varepsilon_{t}$

A non-stationary time series regression generates a spurious results except if the linear combination of the variables eliminates the stochastic trend and produces stationary residuals.

$Y_{t}=\gamma_{1} X_{1, t}+\gamma_{2} X_{2, t} \ldots \ldots \ldots \ldots . \gamma_{k} X_{k}, \square I(0)$

This therefore indicates that variables underconsideration are cointegrated. This test procedure was advocated by Johansen (1988) and Johansen and Juselius (1990).

\section{Analysis of the findings}

\subsection{Descriptive analysis}

The descriptive statistics of the variables used in this study are shown in Table1 below.

Table 1: Descriptive statistics result

\begin{tabular}{|l|c|c|c|c|c|}
\hline & INF & CPE & MPR & INDP & OILP \\
\hline Mean & 20.76528 & 111.9620 & 5.921291 & 4520.877 & 9355.382 \\
\hline Median & 15.40000 & 113.8373 & 6.573750 & 1980.375 & 4708.637 \\
\hline Maximum & 72.80000 & 130.9065 & 11.06417 & 16032.28 & 33623.09 \\
\hline Minimum & 3.200000 & 87.07899 & 0.316667 & 91.60000 & 1696.301 \\
\hline Std. Dev. & 16.82570 & 9.472599 & 3.065399 & 5565.467 & 9719.218 \\
\hline Skewness & 1.450876 & -0.556441 & -0.088774 & 1.097717 & 1.120407 \\
\hline Kurtosis & 4.413586 & 3.292296 & 2.047902 & 2.724848 & 2.802645 \\
\hline Jarque-Bera & 15.62758 & 1.985912 & 1.407021 & 7.343465 & 7.590295 \\
\hline Probability & 0.000404 & 0.370480 & 0.494845 & 0.025432 & 0.022480 \\
\hline Sum & 747.5500 & 4030.633 & 213.1665 & 162751.6 & 336793.7 \\
\hline Sum Sq. Dev. & 9908.649 & 3140.554 & 328.8835 & $1.08 \mathrm{E}+09$ & $3.31 \mathrm{E}+09$ \\
\hline Observations & 36 & 36 & 36 & 36 & 36 \\
\hline
\end{tabular}

Source: Authors own computation from the Eviews result

The table1 above shows the descriptive result for the variables under consideration which include, INF, CPE, MPR, INDP and OILP.The result indicates that all the variables under consideration have positive mean value which ranges from 9355.382 to 5.921291 with a 36 observations. The highest standard deviation of 9719.218 is recorded by OILP while the least standard deviation of 3.065399 is recorded by MPR. The result of the skewness coefficient of the variables shows that two variables, CPE and MPR are negatively skewed, the values are less than zero while the skewness coefficient of the other variables, INF, INDP and OILP are skewed positively. The kurtosis coefficient of the three variables INF (15.62758), INDP (7.343465) and OILP (7.590295) are all leptokurtic, while the kurtosis 
coefficients of the variables CPE (1.985912) and MPR (1.407021) are mesokurtic. The estimation above indicates that the Jarque-Bera probability for the variables shows that the error terms are normally distributed.

\subsection{Correlation}

The relationships among the studied variables depicted in the model above were tested using correlation matrix and the result presented below:

Table 2: Correlation matrix

\begin{tabular}{|l|l|l|l|l|l|}
\hline & INF & CPE & MPR & INDP & OILP \\
\hline INF & 1.000000 & 0.178841 & 0.188516 & -0.082333 & -0.126692 \\
\hline CPE & 0.178841 & 1.000000 & 0.446303 & 0.117274 & 0.109027 \\
\hline MPR & 0.188516 & 0.446303 & 1.000000 & 0.544819 & 0.504025 \\
\hline INDP & -0.082333 & 0.117274 & 0.544819 & 1.000000 & 0.960319 \\
\hline OILP & -0.126692 & 0.109027 & 0.504025 & 0.960319 & 1.000000 \\
\hline
\end{tabular}

Source: Authors own computation from the Eviews result

The correlation result above shows that our focal variables CPE and MPR all have positive relationships with the INF and the variables, INDP and OILP are negative.

\subsection{Unit root test}

In order to assess the time series properties of the data, unit root tests were evaluated. The results of the Augmented Dickey Fuller (ADF) tests are as follow:

Table 3: Stationarity test result

\begin{tabular}{|l|l|l|l|l|}
\hline Variable & \multicolumn{4}{|c|}{ ADF TEST } \\
\hline & $\mathrm{I}(0)$ & Prob. & $\mathrm{I}(1)$ & Prob. \\
\hline INF & -3.061862 & 0.0389 & -5.661320 & 0.0000 \\
\hline CPE & -3.503415 & 0.0138 & -6.181071 & 0.0000 \\
\hline MPR & -1.600512 & 0.4717 & -5.647697 & 0.0000 \\
\hline INDP & -0.437098 & 0.8879 & -5.107374 & 0.0002 \\
\hline D(OILP) & 0.305854 & 0.9748 & -14.71136 & 0.0000 \\
\hline
\end{tabular}

Source: Authors own computation from the Eviews result

The tests indicate that that all the variables are stationary and are integrated of order one at $5 \%$ level of significance both in ADF test procedures; therefore a cointegration test is conducted.

\subsection{Cointegration}

To establish whether long-run relationships exist between variables under consideration, cointegration is therefore conducted using the multivariate procedure. The cointegration tests which include two lags in the Vector Auto Regression (VAR) model are stated as follows: 
Table 4: The cointegration test result

\begin{tabular}{|c|c|c|c|c|}
\hline Eigenvalue & $\begin{array}{c}\text { Likelihood } \\
\text { Ratio }\end{array}$ & $\begin{array}{c}5 \text { Percent } \\
\text { Critical Value }\end{array}$ & $\begin{array}{c}1 \text { Percent } \\
\text { Critical Value }\end{array}$ & $\begin{array}{c}\text { Hypothesized } \\
\text { No. of CE(s) }\end{array}$ \\
\hline 0.731006 & 94.65103 & 68.52 & 76.07 & None ** \\
\hline 0.575258 & 50.00672 & 47.21 & 54.46 & At most 1 * \\
\hline 0.364997 & 20.89346 & 29.68 & 35.65 & At most 2 \\
\hline 0.130793 & 5.453168 & 15.41 & 20.04 & At most 3 \\
\hline 0.020010 & 0.687242 & 3.76 & 6.65 & At most 4 \\
\hline \multicolumn{5}{|c|}{${ }^{*}\left({ }^{* *}\right)$ denotes rejection of the hypothesis at $5 \%(1 \%)$ significance level } \\
\hline
\end{tabular}

Source: Authors own computation from the Eviews result

The result of the cointegration test indicates that there are at most two cointegrating equations. Specifically, the result test suggests that all the variables have a long run equilibrium conditions with INF. This evidence of cointegration among the variables implied that at least one direction of influence could be established among the variables.

\subsection{The VAR models results}

Using variance decomposition and impulse response functions, we analyze dynamic properties of the VAR models. The table below displays the impulse responses of the INF, CPE, MPR, INDP and OILP. The $x$ axis gives the time horizon and the $y$-axis shows the percentage variation in the dependent variable away from its base line level. The solid line in each graph is the estimated response while the dashed lines denote the one standard error confidence band around the estimate. It is interesting to note that the error bands are typically symmetric around the median.

From the impulse response graph presented in Figure 1, the response of the INF to one standard innovation is positive to its own shock in the short run; it fluctuates and then became stable and continues its positive trend along the horizon in the long run. The impulse response of the INF to one standard innovation in the CPE indicates a lower response of negative shock in the initial period with little fluctuation along the horizon and then stabilizes in the long run. The result conforms to Verheyen (2010) study of the US economy which noted an immediate and significant rise of prices to an exogenous increase of the Commodity Research Board (CRB) index. The response of the INF to one standard innovation in MPR shows a little fluctuation in the short run, but steadily continues its positive trend, then fluctuated along the horizon in the long run period. The result conforms to Verheyen (2010) findings that a reduction of commodity prices and consumer prices after a restrictive monetary policy, i.e. a raise of the in the interest, commodity prices decrease immediately (and significantly), consumer prices decline significantly not until one year. The impulse response of INF to one standard innovation in OILP indicates a short run response negatively and it continues along the horizon in the long run. The response of the INF to one standard innovation in INDP indicates a similar response in both short and long run duration. 
Response to O ne S. D. I nnovat ons $\pm 2 \mathrm{~S}$. E

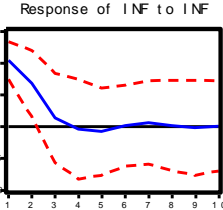

Response of CPE to INF

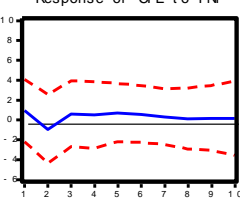

Response of M PR to INF

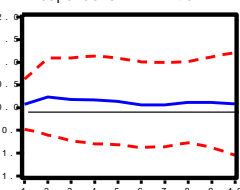

Response of I NDP to I NF

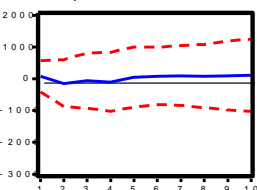

Response of O ILP to I NF

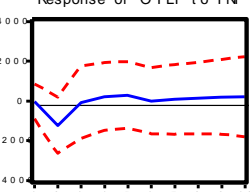

Response of INF to CPE

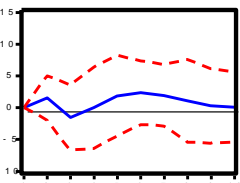

Response of CPE to CPE

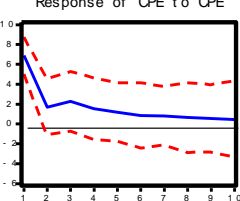

Response of M PR to CPE

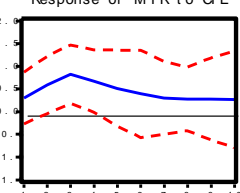

Response of I NDP to CPE

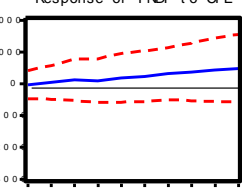

Response of OILP to CPE

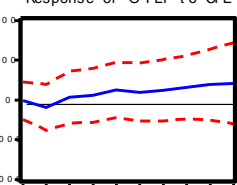

Response of INF to MPR

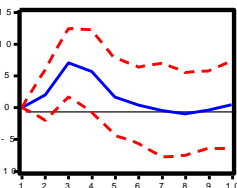

Response of CPE to M PR

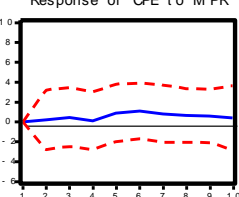

Response of M PR to M PR

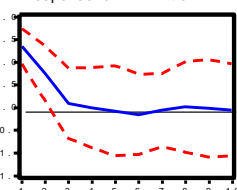

Response of I NDP to M PR

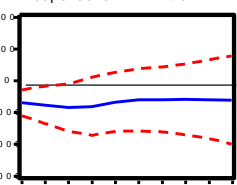

Response of OILP to MPR

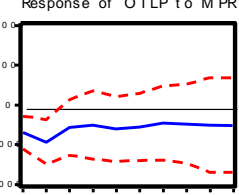

Response of I NF to I NDP

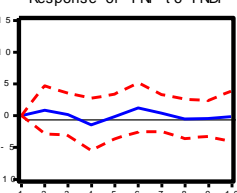

Response of CPE to I NDP

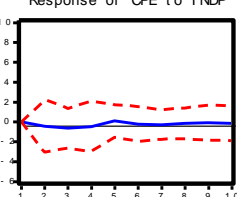

Response of M PR to I NDP

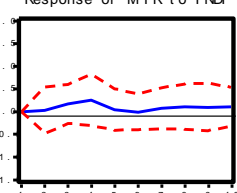

Response of I NDP to I NDP

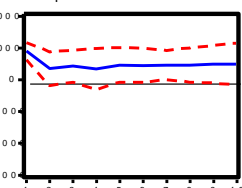

Response of O ILP to I NDP

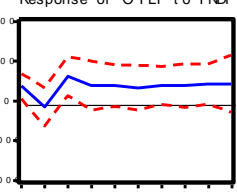

Response of I NF to O I LP

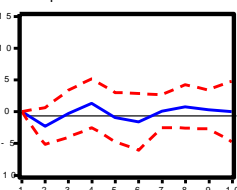

Response of CPE to O ILP

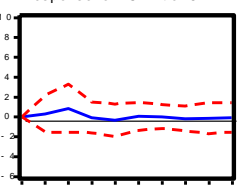

Response of MPR to O ILP

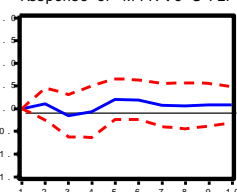

Response of I NDP to O I LP

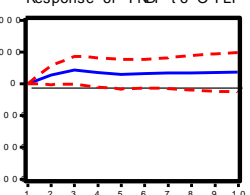

Response of OILP to OILP

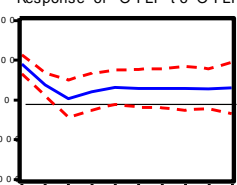

Figure 1: Impulse response function

Source: Authors own computation from the Eviews result

Taking now a look at the other impulse response functions, a response of the CPE function increases in the short run but maintains a positive trend along the horizon in the long run. The impulse response function of the CPE to one standard innovation in INF shocks indicate a negative response in the short run and continues to fluctuate along the horizon in the long run positively. Boughton and Branson (1988) noted that commodity prices could be interpreted as a leading indicator of consumer price inflation, in other words, turning points in commodity prices frequently preceded turning points in inflation. The response of the CPE to its own shock and to that of MPR indicates a similar response; it shows a positive response in the short run and continues on a positive note along the horizon in the long run. The impulse response of the INTR to INF shock indicates a positive response in the short and then declines negatively along the horizon in the long run. The response of the MPR to its own shock, and to CPE show a similar response, indicating positive response in the short run and continues on a positive note along the horizon in the long run. However, the response of INDP and OILP to their own shocks indicates a positive response in both short and long run.

\subsection{Variance decomposition}

The variance decomposition provides complementary information on the dynamic behaviour of the variables in the system. It is possible to decompose the forecast variance into the 
contributions by each of the different shocks. When calculated by the structural shocks, as in the present case, the variance decomposition provides information on the importance of various structural shocks explaining the forecast error variability of INF. Table below shows the variance decomposition over the short term period (1-2 years), medium term (3-4 years) and over the long term (5-10 years). The tables are shown below:

Table 5: Variance Decomposition of INF

\begin{tabular}{|c|c|c|c|c|c|c|}
\hline Period & S.E. & INF & CPE & MPR & INDP & OILP \\
\hline 1 & 10.40960 & 100.000 & 0.000000 & 0.00000 & 0.000000 & 0.00000 \\
\hline 2 & 12.9176 & 92.64116 & 1.355664 & 2.45566 & 0.447687 & 3.099821 \\
\hline 3 & 14.8668 & 70.7907 & 2.12174 & 24.34804 & 0.348465 & 2.391050 \\
\hline 4 & 16.04449 & 60.84671 & 1.82205 & 33.52864 & 1.089261 & 2.713327 \\
\hline 5 & 16.28861 & 59.2743 & 3.08042 & 33.65714 & 1.063648 & 2.92443 \\
\hline 6 & 16.58607 & 57.17362 & 4.98076 & 32.50604 & 1.594260 & 3.74531 \\
\hline 7 & 16.71571 & 56.4346 & 6.18605 & 32.06596 & 1.62473 & 3.688567 \\
\hline 8 & 16.80688 & 55.83253 & 6.52354 & 32.05645 & 1.71094 & 3.876525 \\
\hline 9 & 16.82314 & 55.7337 & 6.539363 & 32.03992 & 1.77895 & 3.908043 \\
\hline 10 & 16.83077 & 55.68699 & 6.534349 & 32.08859 & 1.785435 & 3.904640 \\
\hline
\end{tabular}

Source: Authors own computation from the Eviews result

The result from the table above shows that the variance decomposition of the INF to itself indicates that it accounts for the most of the variability over all periods; it ranges from $92 \%$ in the short run to $55 \%$ in the long run. The shock of INF to CPE shows a decreasing pattern from the first quarter, ranging from $0.1 \%$ in the short run to $6.5 \%$ in the tenth period. Pindyck and Solimano (1993) noted that the uncertainty associated with high and volatile unanticipated inflation has been found to be one of the main determinants of the rate of return on capital and investment. The shock of the INF to MPR indicates a decreasing pattern in the short run from $2.4 \%$, it increases to $24.35 \%$ in the medium run and continues increasing to $32 \%$ in the long run. The hypothesis of a fast reaction of commodity prices in comparison to consumer prices states that as commodity prices react instantaneously, it results to a reduction in interest rates after a tightening of monetary policy (Verheyen, 2010). The shock of INF to INDP and OILP show a decreasing pattern from $1^{\text {st }}$ quarter with a range from $0.4 \%$ and $3.0 \%$ to $1.7 \%$ and $3.9 \%$ in the long run period respectively.

Table 6: Variance Decomposition of CPE

\begin{tabular}{|c|c|c|c|r|r|c|}
\hline Period & \multicolumn{1}{|c|}{ S.E. } & \multicolumn{1}{|c|}{ INF } & \multicolumn{1}{c|}{ CPE } & \multicolumn{1}{c|}{ MPR } & \multicolumn{1}{c|}{ INDP } & OILP \\
\hline 1 & 6.94735 & 1.81034 & 98.18966 & 0.00000 & 0.000000 & 0.000000 \\
\hline 2 & 7.23519 & 3.40308 & 95.9937 & 0.08753 & 0.32975 & 0.18591 \\
\hline 3 & 7.70286 & 3.639641 & 93.47883 & 0.461300 & 0.979221 & .441002 \\
\hline 4 & 7.87986 & 3.85054 & 93.03019 & 0.459925 & 1.275601 & 1.383742 \\
\hline 5 & 8.058682 & 4.470750 & 91.07021 & 1.715161 & 1.23380 & 1.510078 \\
\hline 6 & 8.19940 & 4.789223 & 89.01733 & 3.458389 & 1.273647 & 1.46141 \\
\hline 7 & 8.28497 & 4.825541 & 88.08192 & 4.288145 & 1.371239 & 1.433157 \\
\hline 8 & 8.33964 & 4.787791 & 87.51191 & 4.85255 & 1.386931 & 1.46081 \\
\hline 9 & 8.38235 & 4.78479 & 87.06693 & 5.284790 & 1.384269 & 1.47921 \\
\hline 10 & 8.407897 & 4.79076 & 86.84947 & 5.47019 & 1.411659 & 1.477912 \\
\hline
\end{tabular}

Source: Authors own computation from the Eviews result

The predominant source of variation in CPE forecast errors indicates that it is its own shock. The variation ranged from $98 \%$ to $86 \%$ over the ten-year period. The innovations of CPE to INF and MPR account for the forecast error variance ranging from 1.8 to $4.7 \%$ and 0.8 to 
$5.4 \%$ over the ten year period respectively. This result corroborates with the findings of Verheyen (2010) that changes in commodity prices no longer dominate the evolution of the Federal Funds Rate. Hence, monetary policy has responded less to commodity price developments, probably knowing that the quality of the signals sent by commodity prices has deteriorated (Verheyen, 2010). The result indicates that CPE shocks explains though not dominant proportion of the forecast error variance of the INDP and OILP both in the first and last quarters; it indicates almost $1.41 \%$ and $1.47 \%$ respectively of the variations.

Table 7: Variance Decomposition of MPR

\begin{tabular}{|c|c|c|c|c|c|c|}
\hline Period & S.E. & INF & CPE & MPR & INDP & OILP \\
\hline 1 & 1.38404 & 0.28378 & 4.60175 & 95.11447 & 0.000000 & 0.00000 \\
\hline 2 & 1.700779 & 2.16218 & 14.8187 & 82.6101 & 0.02476 & 0.38411 \\
\hline 3 & 1.915242 & 2.597618 & 30.23708 & 65.4010 & 0.81246 & 0.951822 \\
\hline 4 & 2.05447 & 2.92288 & 37.0466 & 56.8368 & 2.26056 & 0.93314 \\
\hline 5 & 2.132889 & 3.095986 & 40.10304 & 52.85752 & 2.13808 & 1.805364 \\
\hline 6 & 2.18311 & 3.03548 & 41.4911 & 50.9233 & 2.04274 & 2.507281 \\
\hline 7 & 2.20758 & 3.053921 & 42.40990 & 49.8657 & 2.107124 & 2.563350 \\
\hline 8 & 2.231597 & 3.268061 & 43.0300 & 48.80424 & 2.30642 & 2.591189 \\
\hline 9 & 2.25537 & 3.45659 & 43.63161 & 47.7858 & 2.45191 & 2.67399 \\
\hline 10 & 2.27633 & 3.517026 & 44.1502 & 46.96334 & 2.62134 & 2.74806 \\
\hline
\end{tabular}

Source: Authors own computation from the Eviews result

The variance decomposition of the MPR shows that among all the variables, its own shock explains about $82 \%$ to $46 \%$ of the forecast error variance during the period under review. The result from the table also shows that CPE explains about $4.6 \%$ and $44.1 \%$ of the variations. According to Lo (2008), Efficient Market Hypothesis reasoning suggests that commodity prices should respond relatively quickly to news about interest rates. The result reveals that OILP explains about $2.7 \%$ of the changes in the MPR, while INF explain about $3.5 \%$ of the changes in the MPR. The variance decomposition of MPR to OILP and INDP explains about $2.6 \%$ and $2.7 \%$ of the variations in the long run. Like other financial market prices, commodity prices are relatively flexible, and adjust quickly in response to shocks. Any effects of monetary policy announcements on commodity prices likely occur within a short period of the announcement, in contrast with retail prices, which are stickier (Scrimgeour, 2014).

Table 8: Variance Decomposition of INDP

\begin{tabular}{|c|c|c|c|c|c|c|}
\hline Period & S.E. & INF & CPE & MPR & INDP & OILP \\
\hline 1 & 1139.120 & 0.49695 & 0.06680 & 37.4584 & 61.97779 & 0.000000 \\
\hline 2 & 1449.391 & 1.426656 & 0.110100 & 51.04426 & 43.90953 & 3.509451 \\
\hline 3 & 1789.246 & 1.06733 & 0.47773 & 56.13130 & 34.42513 & 7.898507 \\
\hline 4 & 2025.51 & 1.091102 & 0.560833 & 59.70671 & 29.5222 & 9.119156 \\
\hline 5 & 2211.32 & 0.94956 & 1.133367 & 59.28433 & 29.20153 & 9.431209 \\
\hline 6 & 2368.312 & 0.93612 & 1.97207 & 58.2121 & 28.90546 & 9.974169 \\
\hline 7 & 2528.848 & 0.966799 & 3.315884 & 56.5739 & 28.6629 & 10.48047 \\
\hline 8 & 2685.61 & 0.948952 & 4.80272 & 54.9945 & 28.38213 & 10.8716 \\
\hline 9 & 2848.160 & 0.958799 & 6.508097 & 53.2381 & 28.12743 & 11.16751 \\
\hline 10 & 3016.619 & 0.985677 & 8.285364 & 51.5843 & 27.7544 & 11.39013 \\
\hline
\end{tabular}

Source: Authors own computation from the Eviews result

From the table above, the shocks of INDP to itself ranged from $61 \%$ to $27 \%$ over the ten-year periods. One will also note the increasing contribution of the MPR to INDP shock 
over time which ranges from $37 \%$ to $51 \%$ over the ten year period. Omini, Ogbeba and Okoi (2017) noted that output growth of the manufacturing subsector of the Nigerian economy was $1.25 \%$ in the first quarter of 2015 , which indicated an $18.80 \%$ lower than $20.05 \%$ it recorded during the first quarter of 2014. The shock of INDP to CPE and OILP show different pattern from decreasing in the short run and responding positively with $8.2 \%, 18 \%$ and $11 \%$ respectively over the ten year periods.

Table 9: Variance Decomposition of OILP

\begin{tabular}{|c|c|c|c|c|c|c|}
\hline Period & \multicolumn{1}{|c|}{ S.E. } & \multicolumn{1}{c|}{ INF } & \multicolumn{1}{c|}{ CPE } & \multicolumn{1}{c|}{ MPR } & \multicolumn{1}{c|}{ INDP } & OILP \\
\hline 1 & 2392.444 & 0.011858 & 0.04077 & 33.99272 & 9.656463 & 56.29819 \\
\hline 2 & 3400.57 & 13.1448 & 1.23694 & 47.15952 & 5.621870 & 32.83681 \\
\hline 3 & 3802.120 & 10.56952 & 1.108881 & 46.90896 & 15.1243 & 26.28824 \\
\hline 4 & 4039.84 & 9.646802 & 1.28201 & 47.85116 & 16.97158 & 24.24844 \\
\hline 5 & 4374.621 & 8.653938 & 2.400249 & 48.6544 & 17.51184 & 22.7795 \\
\hline 6 & 4613.369 & 7.781460 & 2.808302 & 49.62039 & 17.73737 & 22.05248 \\
\hline 7 & 4827.417 & 7.13703 & 3.562674 & 48.98199 & 18.7266 & 21.59165 \\
\hline 8 & 5053.62 & 6.58628 & 4.76353 & 48.30882 & 19.36281 & 20.97856 \\
\hline 9 & 5311.494 & 6.09405 & 6.37022 & 47.41622 & 20.05875 & 20.0607 \\
\hline 10 & 5574.32 & 5.663463 & 7.945729 & 46.4965 & 20.5449 & 19.34929 \\
\hline
\end{tabular}

Source: Authors own computation from the Eviews result

From the result of the variance decomposition of the OILP obtained, own shock constituted the predominant source of variations for variables in the model. Apart from own shock, the most dominant variable is MPR. All through the ten-period horizon, it maintained an average significant influence of $33 \%$ to $46 \%$. McCarthy (2015) noted that oil price fall as a result oil Saudi Arabia's oil output expansion accounted for one third of the annual retail price index inflation decline of 1986 from $5.7 \%$ to $2.4 \%$ in the United Kingdom in the year 1985 to 1986 . According to the author, the response of monetary policy to oil price shock, is that there is uncertainty regarding transmission effect of such shock to the economy, but a flexible inflation targeting would provide appropriate framework to conduct monetary policy in this situation. The next most significant variables is INDP which maintains an average of $9 \%$ to $20 \%$ throughout the ten periods.

\section{Conclusion}

The commodity prices response to monetary policy and its effect on inflation is an important aspect of monetary mechanism, as commodity prices help to determine a wide range of producer and consumer prices. The study noted four different channels that monetary policy affect commodity prices. The study utilized an unrestricted Vector Auto Regression (VAR) and Cointegration approach for evaluation. From the results obtained, the Unit root test indicates that all the variables are stationary and are integrated of order one at $5 \%$ level of significance both in ADF test procedures. The cointegration test result indicates at most two cointegrating equations. From the impulse response graph above, the response of the INF to one standard innovation is positive to its own shock in the short run; it fluctuates and then became stable and continues its positive trend along the horizon in the long run. The impulse response of the INF to one standard innovation in the CPE indicates a lower response of negative shock in the initial period with little fluctuation along the horizon and then stabilizes in the long run. The response of the INF to one standard innovation in MPR shows a little fluctuation in the short run, but steadily continues its positive trend, then fluctuated along the horizon in the long run period. The impulse response of INF to one standard innovation in OILP indicates a short run response negatively and it continues along the horizon in the long run. The response of the INF to one standard innovation in INDP indicates a similar 
response in both short and long run duration. The variance decomposition result obtained shows that the shock of the INF to itself indicates that it accounts for the most of the variability over all periods; it ranges from $92 \%$ in the short run to $55 \%$ in the long run. The shock of INF to CPE shows a decreasing pattern from the first quarter, ranging from $0.1 \%$ in the short run to $6.5 \%$ in the tenth period. The shock of the INF to MPR indicates a decreasing pattern in the short run from $2.4 \%$, it increases to 24.35 in the medium run and continues increasing to $32 \%$ in the long run. The shock of INF to INDP and OILP show a decreasing pattern from 1 st quarter with a range from $0.4 \%$ and $3.0 \%$ to $1.7 \%$ and $3.9 \%$ in the long run period respectively. The study therefore recommends that the Federal Government's attention should be focused on non-oil agricultural commodities for future and stable economic growth in Nigeria. Equally, a further study should be conducted in this area of research focusing on the dynamics of commodity markets as it affect mono-product export economies.

\section{Acknowledgements}

We appreciate all the editorial staff of the Oradea Journal of Business and Economics (OJBE) and members of the board of faculty of Economic Sciences, University of Oradea, Romania, for providing us an opportunity to publish our paper.

\section{References}

Adams, F. G. and Ichino, Y., 1995. Commodity prices and inflation : A forward -looking price model. Journal of policy modeling, Elsevier, 17(4), pp. 397-426.

Anyanwu, U. and Kalu, A., 2014. The effect of Central Bank of Nigeria (CBN) money supply management on commercial bank loans and advances (CBLA) and output. Singaporean Journal of Business Economics and Management studies, Volume 2.

Anzuini, A., Lombardi, M. and Pagano, P., 2012. The impact of monetary policy shocks on commodity prices. Temi di discussion working papers.

Barsky, R. and Kilian, L., 2001. Do We Really Know that Oil Caused the Great Stagation? A Monetary Alternative. National Bureau of Economic Research Macroeconomics Annual, Volume 16, pp. 137-183.

Blomberg, S. B. and Harris, E. S., 1995. The Commodity-Consumer Price Connection: Fact of Fable?. Federal Reserve Bank of New York Policy Review, pp. 21-38.

Boughton, J. M., Branson, W. H. and Muttardy, A., 1989. Commodity Prices and Inflation: Evidence from Seven Large Industrial Countries. IMF Working Paper, 89(72).

Bruno, M. and Sachs, J., 1985. Economics of Worldwide Stagflation. Cambridge: Harvard University Press.

Cody, B. J. and Mills, L. O., 1991. The Role of Commodity Prices in Formulating Monetary Policy. The Review of Economics and Statistics, 73(2), pp. 358-365.

De Gregorio, J., 2012. Commodity prices, monetary policy and inflation. Prepared for the Conference on Policy Responses to Commodity Price Movements, organized by the IMF and the Central Bank of Turkey, Available from: https://www.imf.org/external/np/seminars/eng/2011/tur/pdf/JDeG.pdf.

De Gregorio, J. and Labbe, F., 2011. Copper, the Real Exchange Rate and Macroeconomic Fluctuations in Chile. In: R. T. Arezki \& Gylfason y A. Sy (eds.), eds. Beyond the Curse: Policies to Harness the Power of Natural Resources. Washington D.C: International Monetary Fund.

Evans, C. L. and Fisher, J. D. M., 2011. What are the implications of rising commodity prices for inflation and monetary policy?. The Federal Reserve Bank of Chicago, https://www.chicagofed.org/ /media/publications/chicago-fed-letter/2011/cflmay2011-286-p df.pd. 
Frankel, J., 2006. Commodity Expectations and Commodity Price Dynamics: the Overshooting Model. American Journal of Agricultural Economics, Volume 68, pp. 344-348.

Frankel, J., 2006. The Effect of Monetary Policy on Real Commodity Prices. In: Campbell, J. ed. Asset Prices and Monetary Policy. Chicago: University of Chicago Press.

Frankel, J., 2014. Effects of Speculation and Interest Rates in a "Carry Trade" Model of Commodity Prices. Journal of International Money and Finance, Volume 42.

Friedman, B. and Kuttner, K., 1993. Economic activity and the short term credit markets: an analysis of prices and quantities. Federal Reserve Bank of Chicago working paper series.

Garner, C. A., 1989. Commodity Prices: Policy Target or Information Variable?' a Note. ournal of Money, Credit and Banking, 21(4), pp. 508-514.

Hamilton, J. D. and Wu, J. C., 2014. Risk Premia in Crude Oil Futures Prices. Journal of International Money and Finance, Volume Elsevier 42, pp. 9-37.

Hotelling, H., 1931. The Economics of Exhaustible Resources. Journal of Political Economy, 39(2), pp. 137-175.

J.A., F., 1986. Commodity Expectations and Commodity Price Dynamics: the Over-shooting Model. American Journal of Agricultural Economics, Volume 68, pp. 344-348.

Johanson, S., 1988. Statistical Analysis of Co-integrating Vectors. Journal of Economic Dynamics and Control, Volume 12, pp. 231-54.

Johanson, S. and Juselius, K., 1990. Maximum Likelihood Estimation and Inference on Co-integration- With Applications to the Demand for Money. Oxford Bulletin of Economics and Statistics, Volume 52, pp. 169-210.

Kuhanathan, A., Sanvi, A. and Lyes, K., 2013. Does Monetary Policy Respond to Commodity Price Shocks?. Banque de France and Paris-Dauphine University.

Lo, A., 2008. Efficient Markets Hypothesis. In: S. Durlauf \& K. Blume, eds. The New Palgrave Dictionary of Economics. Basingstoke: Palgrave Macmillan.

McCarthy, I., 2015. Oil price falls - what consequences for monetary policy?. a Speech given at Durham University Business School, Available from http://www.bankofengland.co.uk/publications/Pages/speeches/2015/806.aspx.

Meltzer, A. H., 2011. Bernanke's '70s show. Wall Street Journal,available at http://online.wsj.com/article/ SB100014240527487047093045761240337.

Meyer, L., 2011. Inflated worries, available from www.nytimes.com /2011/ 03/ 25/ opinion/ 25meyer.html?_r=2\&ref=opinion.: New York Times.

Moosa, I., 1998. Are Commodity Prices a Leading Indicator of Inflation?. Journal of Policy Modeling,, 20(2), pp. 201-212.

Okwo, I., Eze, F. and Nwoha, C., 2012. Evaluation of Monetary Policy Outcomes and Its Effect on Price Stability in Nigeria. Research Journal of Finance and Accounting, www.iiste.org.

Omini, E., Ogbeba, E. and Okoi, O., 2017. Monetary Policy Shocks and Industrial Output in Nigeria. ritish Journal of Economics, Management \& Trade, 16(2), pp. 1-13.

Pindyck, R. and Solimano, A., 1993. Economic instability and aggregate investment. NBER Working Paper no. 4380.

Runkle, D. E., 1987. Vector Autoregressions and Reality. Journal of Business and Economic Statistics, 5(4), pp. 437-442.

Scrimgeour, D., 2014. Commodity price responses to monetary policy surprises. American Journal of Agricultural Economics.

Sims, C., 1987. Bayesian Skepticism on Unit Root Econometrics. Journal of Economic Dynamics and Contro, Volume 12, pp. 463-474.

Svensson, L. E. O., 2005. Oil Prices and ECB Monetary Policy, s.l.: manuscript, www.princeton.edu/_svensson/papers/ep501.pdf..

Utomi, P., 2014. Implications of falling oil prices on Nigeria's economy, s.l.: http://www.ngrguardiannews.com/news/national-news/191553-implications-of-falling-oil-pri ces-on-nigeria-s-economy. 
Verheyen, F., 2010. Monetary Policy, Commodity Prices and Inflation - Empirical Evidence from the US. RUHR Economic papers.

Walsh, C. and Wilcox, J., 1995. Bank Credit and Economic activity. Federal Reserve Bank of Boston, Volume 39, pp. 83-125.

\section{Bio-note}

Ugwu, Ephraim is currently a Lecturer II at the Federal University, Oye Ekiti (FUOYE), Ekiti State, Nigeria. He was previously a Project Manager at the Innovation and Research Centre, FUOYE. He studied Economics at the University of Nigeria, Nsukka and graduated with Bachelor of Science degree in Economics with Second Class Upper division and a Master of Science degree in Economics (Public Finance). As a researcher, Mr. Ephraim's interest is focused on issues relating to public finance and developments especially in the developing economies.

Emma-Ebere Obiajulu is a Lecturer II at Federal University Oye-Ekiti, Ekiti State, Nigeria. Prior to his career in academics, he gained banking experience at the financial Control unit of access bank plc Lagos during the mandatory National Youth Service year. Before joining the youth corp, he obtained a Bachelor's degree in business administration (major in finance and economics) from the American Business School, Paris France after which he gained a master's degree in Financial Economics from University of Leicester, England, UK, and his research interests include microeconomic theory, market microstructure and health economics. 